\title{
Lebanon 1982 - clearance and reinstatement of the devastated refugee camps
}

\author{
P. Hoole, J. W. Stephenson and A. V. Bingham-Hall
}

\section{Mr Hoole}

UNRWA was set up in 1950 by the UN General Assembly to look after the three quarters of a million Arabs who left Israel and moved into the neighbouring Arab states: Syria, Jordon, the West Bank, Gaza and the Lebanon. The Agency now caters for about 2 million. It does not provide or police the refugee camps but it provides the services, which are basically health and education. It operates 650 schools, eight teacher training colleges, family clinics, ration distribution centres and so on. There are 61 refugee camps within the area of operation.

44. The camps are semi-permanent and have electricity, piped water supplies and some sewerage. The people no longer have tents; they have built themselves blockwork shelters.

45. In 1982 the camps in south Lebanon suffered heavy damage to housing, buildings and services at the hands of invading military forces and the Agency had to do something quickly as the refugees had nowhere to live, there were no schools in operation and the Red Crescent network of clinics was no longer available.

\section{Mrs M. A. Beauclair, Rendel Palmer \& Tritton}

It was good that the engineers managed to improve the situation so much in so short a time, given the political conditions and the troubles of the people at the time. How did they cope with the structural repairs and how did the contractors manage to get materials to build things, apart from the huts that the refugees built for themselves?

\section{Mr R. L. Triggs, Fellow}

The Authors say that bills of quantities were prepared. That seems rather a grand title, considering the time they had available and the numbers of people they had available.

48. At the finish, was the contractor paid a reasonable price for the work he had to do?

\section{Ms S. Simmonds, London School of Hygiene and Tropical Medicine}

I was in Beirut in charge of a large international medical team during the war and siege in 1982 and I have returned there subsequently as a consultant on the reconstruction of the health services of Lebanon, not just for the refugees or the World Health Organisation.

50. I can appreciate the emphasis that there was on shelter because of the approaching winter, but was there also any evidence to show that the damaged 
water and sanitation facilities were a public health problem? Were there, for example, increased numbers of cases of diarrhoea or typhoid that might have been related to these damaged facilities?

\section{Mr Triggs}

Why was there no public health problem if there were only primitive sanitation arrangements?

\section{Ms Simmonds}

The people themselves were motivated and were keen to do something about it, which was a major factor. In other disasters throughout the world where the people are not used to having a sanitation system there are major problems because they are not motivated either to build or maintain systems.

53. As far as I know there was no typhoid, but there were few laboratory investigations done during much of the emergency. Typhoid is present in Lebanon, but during the war and siege there were fewer cases of typhoid than normal because the main routes of transmission were cut, the restaurants were closed, there was no fresh fruit, there were no fresh vegetables and the water supply was cut off. What was worrying was the position when the water supply was turned on after the siege in West Beirut, particularly in the main streets where there were damaged water and sewage pipes.

\section{Mr W. R. Waller, John Taylor \& Sons}

It is gratifying that on this occasion water supply and sewerage were considered and dealt with together. Working with a consulting engineer, I often get involved in schemes where the client wants water supplied but has not thought of how to dispose of it after use.

55. How easy was it to extend the water supply systems in the towns to the camps? Were the treatment works functioning properly or had they been completely ruined? Was the supply reliable for 24 hours or was it intermittent, and were there any other problems in extending the distribution systems?

\section{Mrs Beauclair}

Could the Authors elaborate on how the REDR fits in with UN relief? What kind of training is given to engineers before they are sent to a disaster area?

\section{Mr Trigg}

The Authors were not provided with much material equipment. Was this because of lack of money or for political reasons? For example, one would have expected a Land Rover with radio communication between the sites to have been provided, but was this prevented by the Israeli army?

\section{Mr A. Paterson, Bullen and Partners}

If the Authors were advising people going to Lebanon, what would they advise them to take? Is there a handbook which gives an answer to every problem?

59. What did the Authors live in themselves? The conditions seem to have been very difficult. Did they become almost refugees themselves? 


\section{Mr Triggs}

Was all the money from the UN sources spent? The Lebanese government was still functioning in these conditions; there was still electricity and water and presumably their personnel were paid. How does a government in such circumstances get the money to pay its personnel? Does it just print it, because it can hardly collect taxes?

\section{Mr D. Wallace, Instititution of Civil Engineers}

If there was resistance to living in tents and to using communal latrines, was there also an organized resistance to what the Authors were attempting to do?

62. Was the television coverage provided by international or Lebanese television?

\section{Mr M. J. G. Connell, Property Services Agency}

Bearing in mind the political situation and the fact that the government was discouraging, do the Authors think that the UN should have been there at all? Did they wonder what they were doing there when the government started to burn down the tents and forbid certain things?

\section{Messrs Hoole, Stephenson and Bingham-Hall}

We did not actually rebuild anything--that was a clear mandate. Nothing that was knocked down could be replaced. If a building was not actually on the ground, then it was not 'knocked down' and we tried to prop it up and put back what had been displaced. We had no plans of any of the buildings; the work was all done by judgement and experience. We had to decide whether a building could or could not be repaired and to advise the contractors on how to carry out the repairs. There was no shortage of materials for the contractors, provided one was prepared to pay for them. We negotiated on the prices and were mandated by the Director to negotiate any contract for any value.

65. Normally in the Lebanon there is a field engineer who is Lebanese. Once the fighting had died down, he went round the buildings and estimated the damage. We prepared bills of quantities for Sidon, Tyre and Beirut based on these estimates and called for tenders for each area. We had to be seen to do something and we had to go to Beirut and say something was happening even though there was no-one to supervise the work. By inviting tenders the pressure would be reduced until some Swedish engineers arrived to assist in the supervision. The bills were very sketchy but there was a quantifiable amount of work and they seemed preferable to just putting out a schedule of rates. Any item needed that was not in the bills was negotiated later. This was not in accordance with the Agency's normal rules, but it got things done quickly.

66. The price the contractors were paid seemed reasonable under the circumstances. The contractors worked well and completed the work quickly.

67. To our knowledge there was no increase in the occurrence of typhoid. In Lebanon the spread of disease was checked by the delivery of water, the supply of temporary sanitation facilities and the provision of medical care through mobile units to displaced refugees who were living in the open, squatting amid the rubble of their homes or living in garages, shop fronts and the like. Nowhere in Lebanon was a typhoid epidemic reported.

68. Before the emergency all the camps had a piped water supply which generally supplied water directly to many houses; others were supplied by standpipes. 


\section{DISCUSSION}

Each camp was connected to the local municipal water supply; water was obtained from boreholes, springs and sources in the mountains.

69. After the emergency there was considerable disruption to all services and the water supply was very intermittent. Many pipes had been damaged and many leaks were apparent and needed continual repairs. The treatment works in Tyre were extensively damaged and were repaired by UNICEF. Meanwhile many refugees obtained water from springs and standpipes when it was available or from water tankers. The old distribution systems had been badly damaged and generally these were abandoned and a new ring main was installed, connected to existing house connections where possible, and water points were constructed.

70. Where a sewerage system existed repairs were made, but most of the camps relied on pit latrines. We attempted to construct large numbers of these but were thwarted by the refugees. Instead we provided each family with a concrete squatting plate and they constructed their own latrine. Surface water drains were repaired and reconstructed in each camp.

71. With regard to training, each case is different. Some courses are organized through the army and these prepare people for coping with emergency situations as much as possible, bearing in mind that all emergencies are different. Some people may be selected on the basis of previous experience in developing countries. The REDR puts engineers in touch with aid organizations that require engineers of different disciplines. They have about 500 people who are willing to go and help in these situations. It is up to the engineer and the aid organization to arrange salary details and other conditions.

72. On the question of communication, the agency was not allowed to have radio equipment: permission was refused from the Lebanese government.

73. In reply to $\mathrm{Mr}$ Paterson, the best thing one can take to the Lebanon is one's wits. One has to be aware of the wider implications of what one does. Everything one does is watched and will be disliked by someone. One has to try to do what one thinks is reasonable in the circumstances. We were very fortunate to have a director in Beirut who gave us total backing. He agreed with whatever action we took, and this was really the only way in which we could have operated.

74. We lived in flats and hotels in the area, although conditions were far from ideal. Accommodation was in short supply because many buildings had been damaged or destroyed.

75. The Agency money was indeed all spent. UNRWA has a normal running budget, but it does not cover anything like the Lebanon situation, so when the problem started the Commissioner General appealed for funds. Meanwhile to make sure that essential work could be carried out the director in the Lebanon was given the necessary authority and any money that was needed was diverted. He then had total call on all the Agency's resources and gave us the authority necessary to get the work done.

76. The Sidon electricity and water supplies were working but we do not know how they were funded. As a government organization they would not move into the camps which they considered to be the responsibility of the UN. Although they restored their own services outside the camps we were left to do it inside the camps.

78. In reply to $\mathrm{Mr}$ Connell, the Agency has been in the area for the past 30 years. It was mandated by the General Assembly in 1950 to provide services for the Palestinian refugees within the dispersal areas, which include Syria, Jordon, the West Bank, Gaza and the Lebanon. The Agency cannot elect not to provide 
services unless the governments tell it to leave their countries. The Lebanese wanted services provided. The Agency's mandate was renewed in 1984 to provide further services within the existing constraints. The job is very worthwhile. It was the Palestinian refugees who burned down the tents, not the Lebanese government.

79. In reply to $\mathrm{Mr}$ Wallace, the refugees were generally in favour of most of the work we were doing, that is cleaning out rubble from the damaged and destroyed buildings, installing water and sanitation services and repairing schools and clinics. The refugees were objecting to, and the organized resistance was directed against, the provision of tented accommodation. The refugees considered tents to be inadequate and that they should be given blockwork shelters.

80. The situation was obviously highly topical, and was given a great deal of coverage by the international news media. 